Canadian University Music Review

Revue de musique des universités canadiennes

\title{
Bryan R. Simms. The Atonal Music of Arnold Schoenberg 1908-1923. Oxford and New York: Oxford University Press, 2000. ix, 265 pp. ISBN 0-19-512826-5 (hardcover)
}

\section{Robert Falck}

Volume 21, numéro 2, 2001

URI : https://id.erudit.org/iderudit/1014493ar

DOI : https://doi.org/10.7202/1014493ar

Aller au sommaire du numéro

Éditeur(s)

Canadian University Music Society / Société de musique des universités canadiennes

ISSN

0710-0353 (imprimé)

2291-2436 (numérique)

Découvrir la revue

Citer ce compte rendu

Falck, R. (2001). Compte rendu de [Bryan R. Simms. The Atonal Music of Arnold Schoenberg 1908-1923. Oxford and New York: Oxford University Press, 2000. ix, 265 pp. ISBN 0-19-512826-5 (hardcover)]. Canadian University Music Review /

Revue de musique des universités canadiennes, 21(2), 143-146.

https://doi.org/10.7202/1014493ar

All Rights Reserved (C Canadian University Music Society / Société de musique des universités canadiennes, 2002
Ce document est protégé par la loi sur le droit d'auteur. L'utilisation des services d'Érudit (y compris la reproduction) est assujettie à sa politique d'utilisation que vous pouvez consulter en ligne.

https://apropos.erudit.org/fr/usagers/politique-dutilisation/ 
very value system that they outwardly support or (the reverse) reinforce a system that they overtly critique. The danger is equally well exemplified by traditional criticism, which can praise a piece at one moment for powerfully fulfilling the requirements of its genre ... and at another for its novelty in breaking with convention. ... When a game has rules like this, no great composer can ever misstep. And a minor composer may be blamed, rather than praised, for the very same features: following a rule becomes proof of textbook thinking; breaking one, ineptness (pp. 515-16).

The contributors avoid this sort of double-talk through a general avoidance of premature interpretive closure, although if they were taken out of context, the strong dialectical arguments of some authors (including Korsyn, Fink, Burnham, Cook, Everist, and Bowen) might easily be misinterpreted as apologetics for new orthodoxies and privileged contexts.

Rethinking Music is a timely volume that serves a variety of needs. Those who are interested in the disciplinary history of musicology should read the Preface and the essay by Bruno Nettl (Ch. 13) for concise and thought-provoking overviews. Some selections seem ideally suited to graduate seminars, such as introductions to methodologies in music history (Ch. 15-17), theory and analysis (Ch. 2, 5-7, 11), and performance studies (Ch. 10, 11, 19); and others might be useful for courses on gender studies in music (Ch. 21, 22), ${ }^{14}$ music criticism (Ch. 4, 8, 9), Schenkerian theory (Ch. 3-5), and the philosophy of music education (Ch. 21, 22, 24). The volume is sure to have a place in the library of any busy scholar who is seeking an accessible introduction to complex arguments in booming fields like musical semiotics, performancerelated studies, poststructuralist applications, and feminist musicology or simply a refresher course on the philosophy of music. As a whole, the volume can also be read as a microcosm of a far-reaching scholarly dialogue that holds great promise in leading us to a renewed, realigned, reinvigorated musicology.

Alan Dodson

Bryan R. Simms. The Atonal Music of Arnold Schoenberg 1908-1923. Oxford and New York: Oxford University Press, 2000. ix, 265 pp. ISBN 0-19-5128265 (hardcover).

Although every life-and-works treatment of Arnold Schoenberg grapples with the subject of Bryan R. Simms' new book, his is the first book-length study devoted exclusively to it. Because of Schoenberg's huge influence as a composer, teacher and thinker, this subject is central not only to his career, but to the history of twentieth-century music generally. The author's credentials for the job are beyond reproach. He has published extensively on Schoenberg, and because he is a former archivist at the Schoenberg Archive in its Los Angeles days, his command of both published and unpublished sources is extensive and shines through on every page. 
One of the principle aims of this study is to emphasize the diversity of this music, usually lumped together under the problematic rubric "atonal." As the author says, the atonal style had by 1923 "little in common with what it had been in 1909 . . . At first [it] was touched by angst and spurred on by a need for liberation from the past . ..", but "gradually it lost its spontaneous and emotional character, and ... came to rely on methodic controls in the fashioning of its materials" (p. 3). After an introductory chapter tracing the early evolution of atonality, the gradual transformation of the atonal style itself is described in four discrete stages, treated in six chapters. The first is the mixed style associated with the settings of the poetry of Stefan George in the Book of the Hanging Gardens, op. 15 and the String Quartet no. 2, op. 10 especially. A former student of mine aptly dubbed this stage the "twilight zone," and the works thus described are perhaps the most appealing in the composer's œuvre. The second stage includes the fully atonal, and sometimes athematic, piano pieces opp. 11 and 19, the Five Pieces for Orchestra, op. 16, and the monodrama Erwartung, op. 17. The instrumental pieces are treated in one chapter, and Erwartung shares Chapter 5 with its companion piece, the opera Die Glückliche Hand, op. 18, in which the "methodic controls" of the third stage already make their appearance. Chapter 6 describes the further consolidation of this "third stage" in Pierrot lunaire, Herzgewächse and the orchestral songs op. 22. A full chapter is devoted to the incomplete Jakobsleiter and its even more fragmentary precursors. The book's final chapter treats the fourth stage, when Schoenberg was "composing with tones." In this stage, virtually all of the features of the twelve-tone method are in place, though the tone rows used are normally of fewer than twelve tones.

All of this is generally known and has been documented in the past. What sets this treatment apart is its careful documentation of the chronology of events and, more importantly in my view, the intellectual and spiritual journey travelled by the composer. For instance, there is an illuminating discussion of Schoenberg's relationship to the poetry of Stefan George in Chapter 3. This includes the trenchant reminder that Schoenberg's “... . enthusiasm for George was as brief as it was intense" (p. 31), and that he later distanced himself from the author when George was "unfairly implicated as a supporter of National Socialism" (p. 32). George may have been "unfairly implicated," but not because the Nazis found his thought incompatible. (In fact, the new government offered him an honorary post in 1933, which he refused. He died later that same year.) The discussion of artistic and spiritual influences at work in Die Glückliche Hand, Pierrot and Herzgewächse is equally good, and reveals the breadth and depth both of the composer's and the author's reading and their sensitivity to contemporary issues. When the discussion turns finally to the works composed "with tones" in the period from ca. 1920 to 1923, texts are largely absent and the discussion must turn on more purely musical/technical issues.

While the emergence of the "twilight" style might be explained as a natural extension of the common practice of many modernist composers in the first decade of the century, the abrupt and radical stylistic shift to that of opp. 11, 16 , and 17 is rightly regarded as a special repertory. Here a purely evolutionary 
approach seems less persuasive, and Simms appeals to Schoenberg's marital troubles and the spiritual crisis that they precipitated as the probable inspiration for this small and very special group of pieces. The fact that the culminating piece in this puzzle is Erwartung, the most openly "psychological" and Freudian of the composer's works, adds weight to this interpretation, but Simms never commits himself fully to this view. There is an interesting discussion in Chapter 8 of Schoenberg's reasons for choosing, after op. 25, to compose only with rows of twelve tones when he could have just as well continued to compose "with tones" using "basic shapes" of fewer than twelve, but the author commits himself to no single theory about the need to move out of the "twilight zone" into the darkest night of the works of 1909. In other words, Schoenberg could have continued to produce satisfying works in the mixed style of opp. 10 and 15, but he chose not to do so. Simms has not made the all-too-common claim of historical inevitability for any of these developments, and he certainly has not made such a claim for this most purely anarchic stage. A case might be made, however, that the "methodic controls" which led eventually to the twelve-tone pieces were a substitute for the control offered by the attenuated tonality of the "twilight zone." Still, the leap itself remains a mystery.

Another aim of the book is that it is to rest ". . . both on a close analytic study of the works themselves and a review of the historical circumstances through which they came into being" (p. v). I believe that the second part of this mandate has been carried out with greater success than the first, but this is still an all too rare example of a study of this music in which the two aims are nearly in balance. I do not believe that Simms has much that is really fresh to say about the music of stage two (opp. 11, 16, 17 and 19), but at least he avoids any doctrinaire approach to this whimsical music. The discussion of the "twilight zone" begins promisingly enough with a discussion of what Simms calls "triadic tetrachords" (ex. 2.4, p. 17), but only one of these is actually identified in op. 15 , no. 2 . Not surprisingly, perhaps, the more the music relies on "methodic controls," the more that can be said about it. Thus discussion of the works from Jakobsleiter to the Serenade, op. 24 yields more analytical insights than the earlier stages. Indeed, for me, the final chapter is the most compelling one in the book.

I have only a few quibbles about individual issues encountered on this journey. For instance, it is surely misleading, if not downright wrong, to call op. 16, no. 1 a fugue without any qualification at all (p. 75). I do not believe that most listeners will experience this free and quite fantastic piece as a fugue, though it does have fugal features. It seems equally misleading to refer to the "Obligatory Recitative" (op. 16, no. 5) as a waltz. To be sure, it is in 3/8 time throughout and, at least at the beginning, invokes the waltz, but I would challenge Simms, or anyone else, to actually dance to it. Further, Simms invokes the serenades of Mozart as the model for Schoenberg's Serenade, op. 24, but I believe that the Beethoven Septet, op. 20 and the Schubert Octet, which was modeled upon it, are more appropriate historical models. All three exhibit both forward and backward looking features, and all are, in some sense, "neo-classical." 
We know how important unordered hexachordal sets were in the formulation of Schoenberg's most mature twelve-tone style, and it is illuminating to discover that their importance stretches back at least as far as Die Glückliche Hand. There is some discussion of this, especially in connection with the song "Seraphita" from op. 22 (pp. 144-45 and note 83), and at the end of the treatment of Die Jakobsleiter, where the direct influence of Scriabin's "mystic chord"-another hexachordal set-is noted (pp. 176-77). I believe that this topic deserves, if not a separate chapter, at least a more extensive discussion. (An entry for "hexachord" in the index would be a good start in the right direction!) As one example of what is left unsaid, it is worth pointing out that the set which appears both in "Seraphita" and in Die Glückliche Hand comprises two augmented triads a minor second, or a major seventh apart, and these subsets are used explicitly in the passage quoted from the former. Its complement completes each whole-tone scale, which is yet another hexachordal set, and one which was important in the "twilight zone" pieces. This pitch-class set (6-20) continued to fascinate the composer, who used it as the "source set" for the twelve-tone row in his Ode to Napoleon Buonaparte, op. 41, in which triadic references abound. Although both it and the Kammersymphonie, op. 9 lie outside the chronological limits covered by the book, it is perhaps worth pointing out that the horn fanfare theme at the beginning of the latter is also a (diatonic major) hexachord. Furthermore, it is employed both as a theme (rectus and inversus) and as a chord. To be sure, complementarity is not exploited in this early work, but it is probably not a coincidence that the theme/chord uses half of the chromatic gamut.

In sum, this is an important addition to the Schoenberg literature, which sets a high standard for clarity and lack of dogmatism. The style is clear, the analytical method appropriately eclectic, and the conclusions reached generally sound. In particular, Simms refers to pitch-class sets where appropriate, but puts some of the more extravagant claims of the p-c set school firmly in their place. (See particularly the discussion of the "autobiographical hexachord," p. 80.) Translations from German are accurate and idiomatic, and the glossary offers a much-needed clarification of Schoenberg's own theoretical concepts. One could only wish that all of the analytical issues could have been treated more fully than they could be in this rather slim volume of just over two hundred pages.

Robert Falck 